\title{
NEW METHODS SUPPORT AND ACTIVITIES COMMUNICATION AND INFORMATICS AGENCY MEDAN CITY BASED ON KNOWLEDGE MANAGEMENT
}

\author{
Faizal Zaini', Yani Yudha Wirawan'2, Pipa Biringkanae ${ }^{3}$, Deddy Novie Citra Arta ${ }^{4}$ \\ 1,2,3,4 Politeknik Penerbangan Jayapura \\ Email : faizalzaini@gmail.com
}

\begin{abstract}
Knowledge is an important asset to an organization. Knowledge management is a process carried out by an organization to obtain, identity, creating, sharing, and utilizing knowledge or knowledge within the organization. One of the knowledge development models Management that will be used is the Fahmi model an approach developed for implementing knowledge management on government. to support the process government and human resource management to achieve the goals of deep bureaucratic reform develop government human resources professional one. This paper described the readiness of the Local Government of Medan District in implementing e-government to support the North Sumatra Smart province initiative. The research method was carried out quantitatively and qualitatively. Quantitative data was carried out by surveying 30 employees in the Mandailing Natal Government, while qualitative data was carried out by open interviews with informants who came from the Office for Communication and Informatics Services. The study also presents several obstacles to the implementation of government and propose several recommendations as a step towards improvement.
\end{abstract}

Keywords: : knowledge, knowledge management, Fahmi Model.

\section{INTRODUCTION.}

The medan city information and communication office is implementing elements of the medan city government led by the head of the service. its main task is to carry out regional government affairs in the field of communication and information based on the principles of decentralization and assistance tasks. the task of the medan city department information and technologies (diskominfo) is to assist the regional head in carrying out regional household affairs in the field of communication and information as well as carrying out assistance tasks by his field of duty (Case et al., 2014).

An implementation of duties and functions of the medan city information and communication office is manifested in the form of programs and activities that are carried out as a manifestation of commitment to providing services to the community. various efforts have been made to achieve the targets set in the medan city (Cosco et al., 2010). the medan city information and communication agency (2018) has compiled the following programs and activities (Isa Indrawan et al., 2019):

1. Office administration services

2. Improvement of apparatus facilities and infrastructure

3. apparatus discipline improvement

4. apparatus capacity building

5. development of communication, information, and mass media

6. facilities for improving human resources in the information and communication sector

7. information cooperation with the mass media.

8. services and security of encryption.

To optimize performance and community service achievements as well as to anticipate changes that will occur in the future, fundamental steps and policies are needed to achieve 
goals, so that the vision, mission of the medan city information and communication office can be implemented optimally (Akhir et al., 2015).

There are strategic steps that need to be pursued. one of the national development programs in the field of communication and information technology, namely "priority programs for the development of information and public communication through the provision, dissemination, and utilization of information are carried out by the government to actively collect useful information to be accessed by the public, disseminating information. benefit equally to all elements of society ". in the 2016-2021 period, the medan city information and communication agency should be able to support the implementation of regional development acceleration as stipulated in the medan city medium term development plan (rpjmd) 2016-2021 (Sitompul \& Lubis, 2013).

Medan city information and communication agency has a vision that is inseparable from the vision of the medan city government, which is "to become a multicultural, competitive, humanist, prosperous and religious future city". the vision is a description of the direction of development or future conditions that the medan city communication and informatics office wants to achieve in the next 5 (five) years (2016-2021) (Novita \& Siregar, 2019) .

This vision is also a guiding direction for the institution in preparing and implementing its programs and activities. to achieve the above vision, every five years the medan city information and communication agency prepares a strategic plan (renstra), which is further detailed in the form of programs and activities that will serve as performance indicators. in the previous period (2011-2015) the performance achievement based on the strategic plan targets, the average was 86 percent. this average achievement is considered good, however, when viewed from each indicator, it turns out that there are several indicators whose performance ratio is below 50 percent. this is an achievement that is not in line with the vision of a competitive medan city information and communication service (Parasol, 2018).

Any problems in this research there were not achieved optimum results on the programs and activities of the medan city information and communication service which were carried out in the 2010 - 2015 period. the performance was between 40 - 61 percent. these five indicators are activities contained in the programs and activities of the medan city information and communication service. the low ratio of performance achievement in these five indicators is a problem that is expected not to be repeated in the performance achievements of the 20162021 period (Kaur, 2016).

Experience in various companies, for improvement in a positive direction, many use knowledge management in managing their companies. in this context, researchers also want to offer solutions for implementing the knowledge management of the medan city information and communication office, particularly in its programs and activities. based on this problem, it is necessary to research programs and activities through the implementation of knowledge management, so that it will produce innovative and creative programs and activities (Stock et al., 2017).

\section{LITERATUR REVIEW.}

Knowledge management or knowledge management is no longer a new term in the process of scientific development. It is precisely the development of knowledge today that has prompted experts to examine more specifically the dissemination of knowledge in HR development. This is driven by the increasing need for reliable human resources in increasing competitive advantage in an increasingly competitive era. Knowledge management which was initially centralized has begun to be abandoned and is shifting towards dissemination in nature (Ruiz-Ballesteros, 2011). 
This shift is driven by the rapid development of new technologies so that every institution or company has begun to utilize employee knowledge through new models to create, share, and use knowledge (Sugiarto et al., 2018).

Knowledge management is an organizational activity in managing knowledge as an asset, wherein various strategies there is the distribution of the right knowledge to the right people and in a fast time, so that they can interact with each other, share knowledge and apply it in their daily work to improve organizational performance. Knowledge management as cited by Ahmed and Massingham (2018) is a management concept and method that emerged as a business trend in the 1990s and is now an important tool for improving performance in all types of organizations, including business or service-oriented and government and private organizations (Goyal \& Palwalia, 2016).

In simple terms, knowledge management is understood as a process or way to create knowledge, acquire knowledge, capture knowledge, share knowledge, and use knowledge. The emergence of knowledge management is motivated by the belief in the great benefits of knowledge for the organization. Knowledge management is defined by experts differently, because of the diversity of perceptions or opinions about differences in information and knowledge (Deptt \& Jabalpur, 2013).

Information experts say that information is the knowledge that is presented to a person in an understandable form; or data that has been processed or organized to present meaningful facts. Whereas knowledge comes from relevant information that is absorbed and combined in one's mind. Knowledge also relates to what a person knows and understands. Information tends to be real, while knowledge is information that is interpreted and integrated (Evicahyani \& Setiawina, 2016).

Based on the explanation that has been presented above, it can be concluded that knowledge management is an activity that appears to find and utilize intellectual resources in an organization. Knowledge management aims to find, store, share, and share widely the very important resources owned by an organization. Such as someone's expertise, skills, network relationships, and policies that exist in the organization

In the current era, competition between institutions and companies is increasingly competitive, it requires efforts that can be made in creating their knowledge, so that strength is created within the institution or company so that it can be created through innovation that continues to develop dynamically .

There are five reasons for the importance of using knowledge management for every organization:

1. Time and Cost Savings Knowledge management that is applied can make an organization or company spend time or money looking for the same knowledge, every time there is a change in HR in it. Knowledge management makes it easy to find the information needed.

2. Increase Knowledge Assets Knowledge management is applied, so that it can help each individual to improve the competence of each individual. so that the creation of government organizations that are increasingly intelligent and capable of various innovations. Knowledge management is currently not only known in private companies but also government organizations. The difference is, private organizations aim at a profit, whereas government organizations have the ultimate goal of improving public services. Several kinds of literature show that government organizations have initiated the application of knowledge management in government organizations. Its purpose is to facilitate the process of creating, collecting, storing, and sharing knowledge among employees.

3. Creating innovation and change The ability to innovate can be done through knowledge management. Therefore, every manager and business professional need to learn true

New Methods Support and Activities Communication And Informatics Agency Medan City 88 
technology not only in their respective fields but also in the context of the whole company and in an inter-organizational background (Basuki, 2018).

4. Improve the efficiency of each organizational unit of operation Knowledge management can assist an organization or company in evaluating its performance from previous periods so that in the future it can be improved and developed. Knowledge management can increase work efficiency because work can be done quickly with access to information to all resources owned by the organization. By applying an efficient way of working processes and methods, better work results are created. The success of an organization to win the competition can be done by designing and implementing the right strategy. Knowledge management is a superior strategy that organizations can rely on. Every organization must be able to explore the resources, knowledge, and capabilities of the organization. A study conducted by Ahmed and colleagues in August 2017 reported that university librarians in Pakistan have a positive attitude towards knowledge management. Knowledge management offers many advantages for university libraries to increase organizational efficiency (Ahmed, 2018).

5 Increase customer satisfaction

Knowledge management can further increase customer satisfaction. Service will be faster because it is helped by the work skills that employees already have. Services can be performed promptly, because the performance is getting better with the increasingly sophisticated information technology. Organizations can provide answers faster or shorten the time it takes to improve a product or service.

From the objectives stated above, it is clear that the benefits of knowledge management as a well-planned and systematic approach ensure the good application of organizational knowledge. Knowledge management is also useful for increasing ideas, innovation, thinking, competence and expertise. The terms Fernandez and Sabherwal (2010) say, the benefits of knowledge management are for People, Process, Product, and Organization Performance.

Tables 1. The benefits of knowledge management as a planned approach

\begin{tabular}{|l|l|l|}
\hline People & 1) $\begin{array}{l}\text { Providing learning facilities to employees (either from } \\
\text { among employees or from external sources) so that they } \\
\text { develop gradually as a form of response to market and } \\
\text { technology. }\end{array}$ \\
2) $\begin{array}{l}\text { Increase employee learning and sensitivity to the latest } \\
\text { knowledge in their fields, employees will find it easier to } \\
\text { obtain information and knowledge needed to adapt to the } \\
\text { organizational environment. }\end{array}$ \\
3) $\begin{array}{l}\text { Employees learn easier than other organizations that do not } \\
\text { apply Knowledge Management and are better prepared to } \\
\text { face changes. }\end{array}$ \\
4) $\begin{array}{l}\text { Knowledge Management provides employees with a good } \\
\text { solution to problems they have faced before. }\end{array}$ \\
1) $\begin{array}{l}\text { Helping organizations get better by defining and } \\
\text { implementing appropriate processes. } \\
\text { 2) }\end{array}$ \\
Reducing the costs of obtaining and accessing valuable \\
knowledge. \\
3) $\begin{array}{l}\text { Helping individuals create innovative solutions to problems } \\
\text { faced to develop organizational processes. }\end{array}$
\end{tabular}




\begin{tabular}{|c|l|l|}
\hline & 4) $\begin{array}{l}\text { Assist organizations for strategic decision making and } \\
\text { product development in a dynamic environment. }\end{array}$ \\
\hline Products & 1) $\begin{array}{l}\text { Helping organizations offer new products that provide } \\
\text { significant added value compared to previous products. }\end{array}$ \\
2) $\begin{array}{l}\text { Make it easy for organizations to access and combine the best } \\
\text { knowledge to prevent production that is too expensive or too } \\
\text { time-consuming. }\end{array}$ \\
\hline Organizational & 1) $\begin{array}{l}\text { Direct Impacts: Knowledge Management is used to create } \\
\text { innovative products that create a profit when linked to business } \\
\text { strategy. }\end{array}$ \\
2) $\begin{array}{l}\text { Indirect Impacts: Knowledge Management helps organizations to } \\
\text { develop and exploit tangible and intangible resources better than } \\
\text { other competitors. }\end{array}$
\end{tabular}

Observing the description described in the table above, it is clear that knowledge management benefits an organization. Knowledge management provides a concept map to regulate the higher the performance and the performance is more creative and innovative, the work process is more assisted, the time and costs are saved. Knowledge Management can also implement a more efficient strategy for use in advancing an institution or company.

\section{Knowledge Management and Public Services in the Era 4.0}

The era of globalization demands that decisions be made appropriately to compete in an increasingly fierce and competitive industrial environment. Increasing the quality of effectiveness within the organization does not only depend on the equipment in the office, but includes knowledge management which is also inseparable from the management of human resources as an important asset of the company or organization. As a source of knowledge, humans are essentially actors of the processes that exist in knowledge management. Many companies or organizations do not yet know the potential hidden knowledge that their employees have.

The industrial revolution is experiencing its peak today with the birth of digital technology which has a massive impact on human life around the world. The latest industrial revolution or the fourth generation drives the automation system in all activity processes. The increasingly massive internet technology not only connects millions of people around the world, but has also become the basis for trade transactions, online transportation, and other online services.

By these developments, the needs of the community have continued to grow and have increased. The higher the needs of the community, the people demand services that are faster, open and transparent. For that, we need a new model that can solve the various changes that occur quickly. With a fast system, public services can be more optimal, so that all people are well served regardless of their social and economic status. Thus, it can be understood that good public service is one of the factors that can support the progress of regional development.

Public service consists of two words, namely the word service and the word public. Services related to services, as explained by LuKnowledge Managementan (2010), services are activities that are not clear, but provide satisfaction to consumers and / or industrial users and are not tied to the sale of a product or other service. He further explained that service is a sequence of activities that occur in direct interaction with people physically to provide customer satisfaction. Also, Ivancevich, Lorensi Skinner and Crosby (2012) define service as an invisible (intangible) product that involves human efforts and uses equipment.

New Methods Support and Activities Communication And Informatics Agency Medan City 90 Based On Knowledge Management

Oleh : Faizal Zaini, Yani Yudha Wirawan, Pipa Biringkanae, Deddy Novie Citra Arta 


\section{Factors Affecting Public Services.}

Public services will run as expected if the supporting factors are adequate and function efficiently. As explained by Moenir (2010), several factors support the quality of services provided. The factors referred to, namely:

1) the factor of awareness of officials and officers;

2) service regulation factor;

3) organizational factors;

4) officer skill factor;

5) the factor of means in carrying out service tasks. Wolkins, as quoted by Tjiptono (2003), also describes six factors that need to be considered to achieve quality service. These six factors include: 1) leadership,

2) education,

3) planning,

4) review,

5) communication,

6) appreciation and recognition

Based on the two explanations above, it can be concluded that improving the quality of public services is influenced by:

1) organizational culture,

2) leadership,

3) employees' abilities and skills,

4) appreciation and recognition,

5) facilities and infrastructure.

\section{Employee Abilities and Skills}

Customer satisfaction is highly dependent on the quality of service provided by service providers, which is basically the conformity between the perceived services expected by the customer (customer expectation).

The ability and skills of employees to provide services are very important in order to improve the quality of public services. Because the service system is an integral part of a series of interrelated services. If one of the existing systems is disrupted, the service will automatically be interrupted. Thus, the apparatus knowledge about services also determines the quality of public services.

The personnel development process in order to improve overall service performance must meet certain standards and criteria. Employee recruitment can be done based on expertise or education level. This needs to be given attention to suit its function as manager and implementer of public services.

Apart from recruiting employees, improving the quality of officers or employees can also be done through competency development, namely the development of service management knowledge. This competency development can be done through continuous education and training. Education and training for employees is very important in order to equalize work perceptions. Skills can be learned through practice, apprenticeship, up grading and so on.

From the description above, it is clear that employee performance also affects the services served. Vroom as quoted by As'ad (2010) states, performance is the extent to which a person is successful in carrying out his job duties. This is what he later called the level of performance. An organization or agency actually needs real work, not just formalism. This is one aspect that must be considered by an organization. The result of this mismanagement is the occurrence 
of disappointment, even a sense of frustration because the performance is not in accordance with the desired expectations.

The emergence of work formalism, as stated by Kismartini, is because the performance standards of public organizations are often considered a problem of managers or superiors. In some cultural characteristics of public organizations, the focus of performance is much on the institution, and not on individual employees. Whereas organizational performance is a cumulative aggregation of individual performance. In fact, often individual performance itself has never been designed, implemented or monitored. Alewine as quoted by Kismartini (2010), states that the work standards of an employee must be realistic and must be measurable. Work standards can be said to be satisfactory if the statement shows some of the main responsibilities of employees, contains how a work activity is carried out, and directs attention to quantitative mechanisms.

\section{METHOD OF RESEARCH.}

The selection of the Medan City Information and Communication Office as the object of research, that the Medan City Communication and Informatics Office is implementing elements of the Medan City Government led by the Head of the Service. Its main task is to carry out regional government affairs in the field of communication and information technology based on the principles of decentralization and assistance tasks. The task of the Medan City Information and Communication Office is to assist the Regional Head in carrying out regional household affairs in the field of communication and information as well as carrying out assistance tasks in accordance with his field of duty. In the 2016-2021 period, the Medan City Information and Communication Agency should be able to support the implementation of regional development acceleration as stipulated in the Medan City Medium Term Development Plan (RPJMD) 2016-2021.

The Medan City Information and Communication Agency has a vision that is inseparable from the vision of the Medan City Government, which is "To become a Multicultural, Competitive, Humanist, Prosperous and Religious Future City". The vision is a description of the direction of development or future conditions that the Medan City Information and Communication Office want to achieve in the next 5 (five) years (2016-2021), besides that this vision is also a guide for the institution in preparing and implementing programs. and activities. As mentioned in the background, there are still 5 (five) indicators that have achieved performance based on the Strategic Plan targets for the previous period (2010 - 2015) with the achievement ratio between 40 - 61 percent. These five indicators are activities contained in the Medan City Information and Communication Agency program.

As a government institution, of course, this achievement is a red report card that is not expected to happen. Details can be seen in the table below.

Tables 2. Achievement Ratio

\begin{tabular}{|c|l|l|}
\hline No. & \multicolumn{1}{|c|}{ Performance Indicators } & $\begin{array}{l}\text { Performance } \\
\text { Ratio (\%) }\end{array}$ \\
\hline 1. & Development and operationalization of running text & 40 \\
\hline 2. & Billboard construction and operation & 40 \\
\hline 3. & Information dissemination such as big day events & 44 \\
\hline 4. & $\begin{array}{l}\text { Disseminate information such as VCD / DVD playback } \\
\text { information }\end{array}$ & 52 \\
\hline 5. & $\begin{array}{l}\text { Dissemination of information through interactive media } \\
\text { dialogue, lectures and face to face }\end{array}$ & 61 \\
\hline
\end{tabular}

New Methods Support and Activities Communication And Informatics Agency Medan City 
In the table above, there are 5 (five) indicators whose achievement ratio is only between 40-61 percent, namely the development and operation of running text $(40 \%)$, construction and operationalization of billboards (40\%), dissemination of information through big day events (44\%). ), disseminating information through VCD / DVD playback $(52 \%)$ and disseminating information through interactive dialogue, lectures, and face-to-face media $(61 \%)$.

The low ratio of performance achievement in these five indicators is a problem that is expected not to be repeated in the performance achievements of the 2016-2021 period. Considering that this performance indicator is related to the programs and activities of the Medan City Information and Communication Service, the focus of this research is the programs and activities of the Medan City Information and Communication Office.

The first and second indicators relate to development which is usually adjusted to the available budget. While the third, fourth, and fifth indicators are related to the dissemination of information that requires certain theories and knowledge, especially theories related to communication science. Therefore, in this study, the sub-focus is (1) Information dissemination through big day events, (2) information dissemination through VCD / DVD playback, and (3) information dissemination through interactive dialogue media, lectures, and face-to-face. These three activities are under communication, information, and mass media development program.

Experience in various companies, for improvement in a positive direction, many use Knowledge Management in managing their companies. In this context, researchers also want to offer solutions for implementing Knowledge Management at the Medan City Information and Communication Office, especially in its programs and activities.

The method used in this research is qualitative research methods. Qualitative research results emphasize meaning rather than generalization (Sugiyono, 2014). Qualitative research methods prefer to use in-depth analysis techniques, namely examining problems in a case by case basis because qualitative methods believe that the nature of a problem will be different from the nature of other problems (Echdar, 2017). Qualitative research is a research procedure that produces descriptive data in the form of written or spoken words from people and observed behavior. So, in this case, it is not permissible to isolate individuals or organizations into variables or hypotheses, but it is necessary to view them as part of a need. Qualitative research will be carried out, taking the case study type (single case study). According to Raharjo (2017), there are twelve steps required in case study research, namely

(1) Theme Selection,

(2) Literature Reading,

(3) Formulation of Research Focus and Problems,

(4) Data Collection,

(5) Data Completion,

(6) Data Processing,

(7) Data Analysis,

(8) Data Analysis Process,

(9) Theoretical Dialogue,

(10) Triangulation of Findings (Confirmability),

(11) Conclusion of Research Results and

(12) Research Reports.

The researchers will follow all these steps in stages in sequence.Typically in qualitative research, the researcher acts as the main research instrument (research instrument). In-depth interviews (in-depth interviews) are interview techniques used in qualitative research to extract the data needed in research. In the interview, it involves two parties, namely the

New Methods Support and Activities Communication And Informatics Agency Medan City 93 Based On Knowledge Management

Oleh : Faizal Zaini, Yani Yudha Wirawan, Pipa Biringkanae, Deddy Novie Citra Arta 
interviewer who asks the question and the interviewee who provides the answer to the question. Through interviews, researchers can explore not only what is known and experienced by the person / subject being studied, but also what is hidden deep within the research subject (explicit knowledge and tacit knowledge). Apart from that, what was stated to the informants could include things that are cross-time related to the past, present, and also the future. Researchers conducted direct interviews with informants at the research location using a recording device, because the recording device was seen as helping hearing, in addition to the interview transcript in written form. Interviews were conducted with research informants, both key informants and key informants and additional informants. Key informants and key informants were selected directly from the Medan City Information and Communication Agency officials. Among them are Head of Services (Zain Noval), Secretary (Mansursyah), Head of Program and Activity Development (Khairunnisa). Meanwhile, the number of additional informants is not limited to the number of people who are considered to be able to provide information even though they are not directly involved in the preparation of programs and activities of the Medan City Communication and Information Agency. 2. Observation Observations were made indirectly (non-participant observation) on knowledge management activities carried out by the Medan City Information and Communication Agency. However, in this activity the researchers continued to observe various events that were considered important as research data. The aim is to gather information from observations on the application of knowledge management by the Medan City Information and Communication Office. Through observation, researchers also want to see the atmosphere of daily activities at the Medan City Information and Communication Office and see the services provided to the community. 3. Documentation In this case the researcher uses documentation data belonging to the Medan City government that is relevant to the research objectives. Documentation data is also obtained from photographs, newspapers, journals, the official website of the Medan City government, books and relevant research results that are recognized for their scientific accountability.

\section{Vision and Mission}

\section{ANALYZE AND RESULT.}

In this section, the thing to do is describe the vision and mission in the Dinas Communication and Informatics of Medan City.

Vision and the mission provides a deep picture apply and develop knowledge management at the Department of Communication and Medan City Informatics.

- Vision

Realizing good knowledge management within the Department of Communication and Information Technology Medan city.

- Mission

- Increase every knowledge asset employees.

- Developing knowledge management good and reliable system.

- Increase every innovation and creativity employees.

- Instilling a culture of sharing knowledge on every employee.

\section{Critical Success Factor}

Critical Success Factor is a critical factor which determines the success in implementation Knowledge Management in the City Information and Communication Office Medan. This Critical Success Factor consists of 3 factors, namely Human, Organization, and Technology.

1. Human

New Methods Support and Activities Communication And Informatics Agency Medan City 
Humans are a very important factor in the successful application of Knowledge Management and Knowledge Management development at the Department of Communication and medan City Informatics. That human referred to are employees of the Communication Service and Informatics for Medan City. If the employees neither sharing knowledge nor mutual exchanging knowledge then the application of Knowledge Management is not will work. With an exchange knowledge carried out by Dinas staff Communication and Informatics of Medan City making this Knowledge Management implementation successful.

2. Organization

Organization is also a factor

determinants of the success of implementing Knowledge Management. Knowledge team management consists of:

- Team leader, who has a duty as full responsibility for implementation and development of knowledge management on City Information and Communication Office Medan.

- Development team, which has a task in application development and maintenance knowledge management system used and hardware and networking ones used.

- Administrators, who are responsible for manage user access and ensure the system continues to run properly.

3. Technology

Information technology also has a role important in the application and development of Knowledge Management. Without technology, knowledge cannot be managed effectively and the application of Knowledge Management will so many obstacles that can create an implementation of Knowledge Management will fail. In this section, the thing to do is determine which information technology will be used in information technology infrastructure to support Knowledge Management. In the application of knowledge this management of information technology to be used are servers, databases, hubs, wi-fi, printers, scanners, and multiple computers / PCs.

\section{KM Mechanisms and Technologies}

Is a means of organization that is used to develop KM such as organizational policies, inter-cooperation projects department, KM Technologies are information technology that can be used to facilitate KM. Thus, KM Technologies are not intrinsically different from information technology, but they are focus on KM rather than information processing. Knowledge Management System application developed based on the web using language PHP programming and DBMS used is MySQL. D. Knowledge Management System In this section we analyze, design, and implementing KMS which supports the knowledge discovery system, knowledge capture system, knowledge sharing system, and knowledge application system. E. KM cycle is a management cycle knowledge or knowledge management that describes how knowledge or knowledge acquired (acquire), verified (verified), stored (store), distributed (share), and utilized (utilize) in an organization.

- Acquire, the process of gaining the knowledge necessary to create decisions, solve problems, or innovate. Knowledge is not just acquired from the internal Communication and Information Technology Office Medan City but it can also be obtained from the environment outside the Department of Communication and Medan City Informatics.

- Verified, the process of verifying or checking the knowledge that has been obtained is it according to your needs. 
- Store, at this stage the process is carried out is collecting and storing knowledge. Collected knowledge and stored it is organized so that it can be retrieved quickly and easily by the user.

- Share, the process of sharing or exchanging knowledge that occurs in the Communication Office and Informatics for Medan City. The goal is to encourage learning sustainable to achieve business goals organization.

- Utilize, the process of utilizing or using existing knowledge within the organization, like practicing inward knowledge action. F. KM process

- A combination is the process of combining various explicit knowledge which is different for organized into a knowledge management system. explicit knowledge that was just discovered through the Combination process. Examples of applications are using data mining techniques to find a new relationship between existing explicit data to create new knowledge. But deep In this research, the Combination process was not researched because the process requires additional complex methods in data processing mining.

- Externalization is a process documenting tacit knowledge to be a form of explicit knowledge that is easy to understand, structured, and clear. This helps translate tacit knowledge of a person in an explicit form which can be more easily understood by others. The form of application in KMS is Form share documents.

\section{Organizational Core Knowledge}

There are 2 types of knowledge that are many found at the Communication and Information Technology Office Medan City, namely:

- Document-Based Knowledge

Document-Based Knowledge is explicit knowledge contained in the Communication Office and Medan City Informatics such as Standards OperationalProcedure (SOP), results of meetings / minutes meetings, annual work program reports, and others.

- Problem Solving Knowledge

Problem Solving Knowledge is tacit knowledge contained in the Communication Office and Informatics for Medan City. Problem Solving Knowledge possessed by Dinas employees Communication and Informatics of Medan City in the form of a solution to a work-related problem and official activities. This knowledge is still stored in the brains of each employee, but not yet documented.

\section{CONCLUSION.}

From this research, it can be concluded that fahmi Model can be used for implementing Knowledge Management in the Office Communication and Informatics of Medan City although some components are not conducted research. By implementing Knowledge Management, Medan City Information and Communication Office can document and manage knowledge well so that it can be searched with easy when needed. Service employees Communication and Informatics of Medan City can documenting knowledge or knowledge owned and distributed to employees other. Besides that, with the implementation Knowledge Management can improve the performance of the employees of the Communication and Office Medan City Informatics.

\section{REFERENCES}

Akhir, R., Hassan Miraza, B., Matondang, R., \& Deni Djakapermana, R. (2015). Policy Space Utilization in Developing Area Medan - Binjai - Deli Serdang (Mebidang) Indonesia. International Journal of Regional Development, $3(1)$, 1. 
https:// doi.org/10.5296/ijrd.v3i1.8501

Basuki, L. (2018). Effect of Active Learning Through Integrating Soft Skills Student Alwashilah Wonorejo Simalungun. In International Journal for Innovative Research in Multidisciplinary Field (Vol. 4, Issue 5).

Case, A., Serdang, D., \& Tarmizi, H. B. (2014). An Analysis of Influencing Factors on Poverty in Sustainability Development Framework : 6(7), 581-590.

Cosco, N. G., Moore, R. C., \& Islam, M. Z. (2010). Behavior mapping: a method for linking preschool physical activity and outdoor design. Medicine $\mathcal{E}$ Science in Sports $\mathcal{E}$ Exercise, 42(3), 513-519.

Deptt, E., \& Jabalpur, J. E. C. (2013). CONTROL OF STARTING CURRENT IN THREE PHASE Sharda Patwa. 01, 27-32.

Evicahyani, S. I., \& Setiawina, N. D. (2016). Analisis Faktor-Faktor yang Mempengaruhi Kualitas Laporan Keuangan Pemerintah Daerah Kabupaten Tabanan. E-Jurnal Ekonomi Dan Bisnis, 5.3, 403-428.

Goyal, S. K., \& Palwalia, D. K. (2016). Analysis of performance parameters and estimation of optimum capacitance for asynchronous generator. Engineering Science and Technology, an International Journal, 19(4), 1753-1762. https:/ / doi.org/10.1016/j.jestch.2016.05.015

Isa Indrawan, M., Alamsyah, B., Fatmawati, I., Samrin, Rusiadi, Shindi Indira, S., Nita, S., Manshuruddin, Siregar, M., Pramono, C., Wahyono, T., Afrina Siregar, N., Sebayang, S., Putera Utama Siahaan, A., Dharma Tuah Putra Nasution, M., Aryza, S., Andoko, Sembiring, R., Novalina, A., ... Sastra Pengalaman Tarigan, A. (2019). UNPAB Lecturer Assessment and Performance Model based on Indonesia Science and Technology Index. Journal of Physics: Conference Series, 1175(1). https://doi.org/10.1088/17426596/1175/1/012268

Kaur, K. (2016). A Study of Vehicular Information Network Archifecture based Named Data Networking (NDN). 140(6), 34-39.

Novita, E., \& Siregar, E. S. (2019). A Cases Relationship Between Internal Locus Control and Vocational Maturity among Students in Medan, Indonesia. 6(2), 1-7. https://doi.org/10.5296/jsss.v6i2.Accepted

Parasol, M. (2018). The impact of China's 2016 Cyber Security Law on foreign technology firms, and on China's big data and Smart City dreams. Computer Law and Security Review, 34(1), 175-179. https:// doi.org/10.1016/j.clsr.2017.05.022

Ruiz-Ballesteros, E. (2011). Social-ecological resilience and community-based tourism: an approach from Agua Blanca, Ecuador. Tourism Management, 32(3), 655-666.

Sitompul, M., \& Lubis, A. (2013). Analisis Sumber-sumber Pendapatan Asli Daerah sebagai Modal Pembangunan. Jurnal Ilmu Pemerintahan Dan Sosial Politik, 1(1), 1-10. http://www.ojs.uma.ac.id/index.php/jppuma/article/download/547/876

Stock, T., Obenaus, M., Slaymaker, A., \& Seliger, G. (2017). South Africa A model for the development of sustainable innovations for the early phase of the innovation process. Procedia Manufacturing, 8(October 2016), 215-222. https:// doi.org/10.1016/j.promfg.2017.02.027

Sugiarto, A., Sihombing, M., Rini, E. S., \& Utara, U. S. (2018). ENHANCEMENT TECHNOLOGY IN ROLES AND INFLUENCE OF HEADMAN FOR IMPROVEMENT URBAN AFFAIRS IN BINJAI ,. 9(11), 1772-1780. 